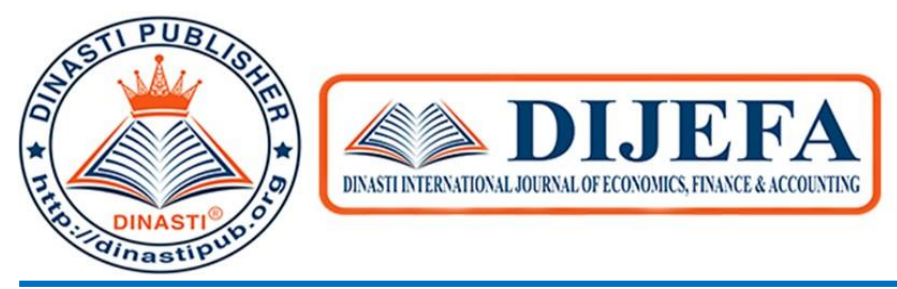

+6281387654578 ?

+6281387654578 (Q)

https://dinastipub.org/DIJEFA (-)

dinasti-info@gmail.com @

\title{
LITERETURE REVIEW FACTORS AFFECTING EMPLOYEE PERFORMANCE: COMPETENCE, COMPENSATION AND LEADERSHIP
}

Az Zahra Tania Arifani', Azzalia Yuniar Susanti ${ }^{2}$

${ }^{1,2)}$ Student of Politeknik Keuangan Negara STAN, Tangerang Selatan, Indonesia

ARTICLE INFORMATION

Received: 25 July 2020

Revised: 13 August 2020

Issued: 23 August 2020

Corresponding Author: First author

E-mail:

azzahrataniaa@yahoo.com azzaliayuniar@gmail.com

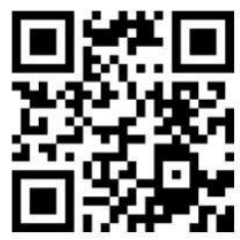

DOI:10.38035/DIJEFA
Abstract: The rapid development of the times accompanied by increasingly sophisticated technology has an impact on various company activities, especially on managerial aspects. Even though companies and organizations have modern technology, companies are still tied to human labor. Human resources are an important factor in an organization so that humans are a strategic factor in organizational management. Human resources are very important to be given direction and guidance from human resource management in order to produce optimal performance. Employee performance is an individual matter depending on the level of different qualifications of each individual which reflects the quantity and quality of something that is produced or done by the worker. This research was conducted by looking at the three factors that are considered to have an effect on employee performance, namely competency, compensation, and leadership style factors through various relevant research methods and can explain in detail the relationship between performance factors.

Keywords: Competence, Compensation, Leadership Style, Performance

\section{INTRODUCTION}

Human resources are an important factor in an organization, so that humans are a strategic factor in organizational management. The company cannot be separated from human labor even though the company already has modern technology. Employees are the main asset for the company, so that human resources are very important to be given direction and guidance from human resource management so that they can improve their abilities, produce work productivity, and produce the expected output. 
To meet expectations of future employee productivity levels, there are several factors that influence this, namely job satisfaction factors, communication factors, work experience factors, discipline factors, motivation factors, leadership factors, competency factors, compensation factors, and work environment factors.

In this case, we want to raise three factors that influence employee performance, namely competency factors, compensation factors, and leadership styles in the organization. The selection of these factors is based on that these factors have a major effect on employee performance. This study aims to analyze the influence of competency factors, compensation factors, and leadership styles in the organization by looking at the point of view of good human resource management. We will cover all of these sections in this article.

Based on the background of the problem above, the problem formulation of this article is to review the theory of the influence of the independent variable on the dependent variable:

1) Does Competence affect Employee Performance

2) Does Compensation affect Employee Performance

3) Does Leadership affect Employee Performance

\section{LITERATURE REVIEW}

\section{Employee performance}

Performance is the result of work both in quality and quantity achieved by a person in carrying out tasks according to given responsibilities (Mangkunegara, 2002). Employee performance is a performance as a result of performance that can be achieved by a person or group of people in an organization both qualitatively and quantitatively, in accordance with their respective authorities, duties and responsibilities in an effort to achieve the goals of the organization concerned legally, does not violate the law and in accordance with morals or ethics (Moeheriono, 2012). Achievement or performance is a record of the results obtained from certain job functions or activities during a certain period of time (Bernadin \& Russel, 2006).

The performance has been examined by many previous researchers, including: (Ali, Limakrisna, et al., 2016), (Prihartono \& Ali, 2020), (Ansori \& Ali, 2017), (Harini et al., 2020), (Riyanto , Pratomo, et al., 2017), (Brata, Husani, Hapzi, 2017), (Agussalim, Kristin, et al., 2016), (Agussalim, Kristin, et al., 2016), (Ali, Limakrisna, et al., 2016), (Desfiandi et al., 2017), (Sulaeman et al., 2019), (Ansori \& Ali, 2017), (Djojo \& Ali, 2012), (Riyanto, Sutrisno, et al., 2017 ), (Prayetno \& Ali, 2017), (Ridwan et al., 2020), (Djoko Setyo Widodo, P. Eddy Sanusi Silitonga, 2017), (Agussalim, Ayu Rezkiana Putri, et al., 2016),

From several theories regarding performance, it can be concluded that performance is a result of work or the level of success achieved by workers in their field of work which can be directly reflected in the output produced both in terms of quantity and quality, according to the criteria applied to the job. Which can be measured through 1) technical ability; 2) Conceptual skills; 3) Responsibility; 4) Initiatives; and 5) Interpersonal relationship skills.

\section{Competence}


Competence is a fundamental factor that exists in someone who has more abilities and makes him different from other people with average abilities (Mangkunegara, 2002). Competence is an ability or the capacity of a person to perform various tasks in a job, where this ability is determined by intellectual and physical factors (Robbins \& Coulter, 2018). Job competence is the work ability of each individual which includes aspects of knowledge, skills, and work attitudes in accordance with established standards (Law No.13 of 2003 on Manpower). Previous researchers have examined many competencies, including: (Ansori \& Ali, 2017), (Ridwan et al., 2020).

From some of the above opinions, it can be concluded that competence is a specification of knowledge and skills and the application of these knowledge and skills in a job or company or across industries, in accordance with the required performance standards. Competence is broadly divided into two, namely technical competence and non-technical competence. Where technical competence can be measured through: 1) level of education; 2) work experience; and 3) ability to analyze. Meanwhile, non-technical competencies can be measured through: 1) Self-Control; 2) Self Confidence; 3) Flexibility; and 4) Attitude.

\section{Compensation}

The compensation system is a part (partial) of the reward system which is only related to the economic part (Long \& Sigh, 2017). Compensation is everything that employees receive in return for their work (Handoko, 2003). Compensation is all income in the form of money, direct or indirect goods received by employees in return for services provided to the company (Hasibuan, 2000). Compensation has been researched by many previous researchers, including: (Riyanto, Pratomo, et al., 2017), (Purba et al., 2017).

This article explains that if the compensation provided by a company or organization can be given well, either in the form of financial compensation or non-financial compensation. Then this will also be followed by an increase in employee performance in the form of technical skills, conceptual abilities, responsibilities, initiatives; and interpersonal relationship skills.

\section{Leadership}

Leadership is the ability to influence a group to achieve goals (Robbins \& Coulter, 2018). Leadership is something that is inherent in a leader in the form of certain traits such as personality, ability, and capability (Wahjosumidjo, 1987). Leadership is a series of structuring activities in the form of the ability to influence the behavior of others in certain situations so that they are willing to work together to achieve predetermined goals (Sutarto, 1998).

Leadership has been studied by many previous researchers, including: (Limakrisna et al., 2016), (Bastari et al., 2020), (Anwar et al., 2020), (Ali, Mukhtar, et al., 2016), (Djoko Setyo Widodo, P. Eddy Sanusi Silitonga, 2017), (Chauhan et al., 2019), (Elmi et al., 2016).

From some of the above opinions, it can be concluded that leadership is someone who uses authority and responsibility to influence members of the organization in order to achieve goals. Which can be measured through 1) Intelligence (Intelligence); 2) Awards; 3) Motivate; and 4) Cooperating with subordinates. 


\section{RESEARCH METHODS}

The method of writing scientific articles is by qualitative methods and literature study or Library Research. Reviewing literature books in accordance with the theory discussed, especially in the scope of Human Resource Management (HRM). Besides, it analyzes reputable scientific articles as well as scientific articles from journals that are not yet reputable. All cited scientific articles are sourced from Mendeley and Google Scholar.

In qualitative research, literature review should be used consistently with methodological assumptions. This means that it must be used inductively so that it does not lead to the questions posed by the researcher. One of the main reasons for conducting qualitative research is that it is exploratory in nature (Ali \& Limakrisna, 2013).

Furthermore, it is discussed in depth in the section entitled "Related Literature" or literature review ("Review of Literature"), as the basis for formulating hypotheses and will then become the basis for making comparisons with the results or findings revealed in the research. (Ali \& Limakrisna, 2013).

\section{RESULTS AND DISCUSSION}

\section{Result}

\section{Employee Competence and Performance}

Competence is an ability or the capacity of a person to perform various tasks in a job, where this ability is determined by intellectual and physical factors (Robbins \& Coulter, 2018). Thus, competence shows the skills and abilities acquired intellectually and physically in a job.

Based on Windows Theory, each individual has competencies that can be observed from four sides in the form of windows, namely: education, skills, work experience, and mastery of technology.

Organizations and companies must be required to have employees who are superior in their fields so that the resulting work practices are maximized as expected. According to Robbins \& Coulter (2018), there are eight activities which are processes in producing highperformance work practices. The first three activities ensure that competent employees are identified and selected, the next two activities provide employees with up-to-date skills and knowledge, while the last three activities ensure that the organization retains competent and high-performing employees. 


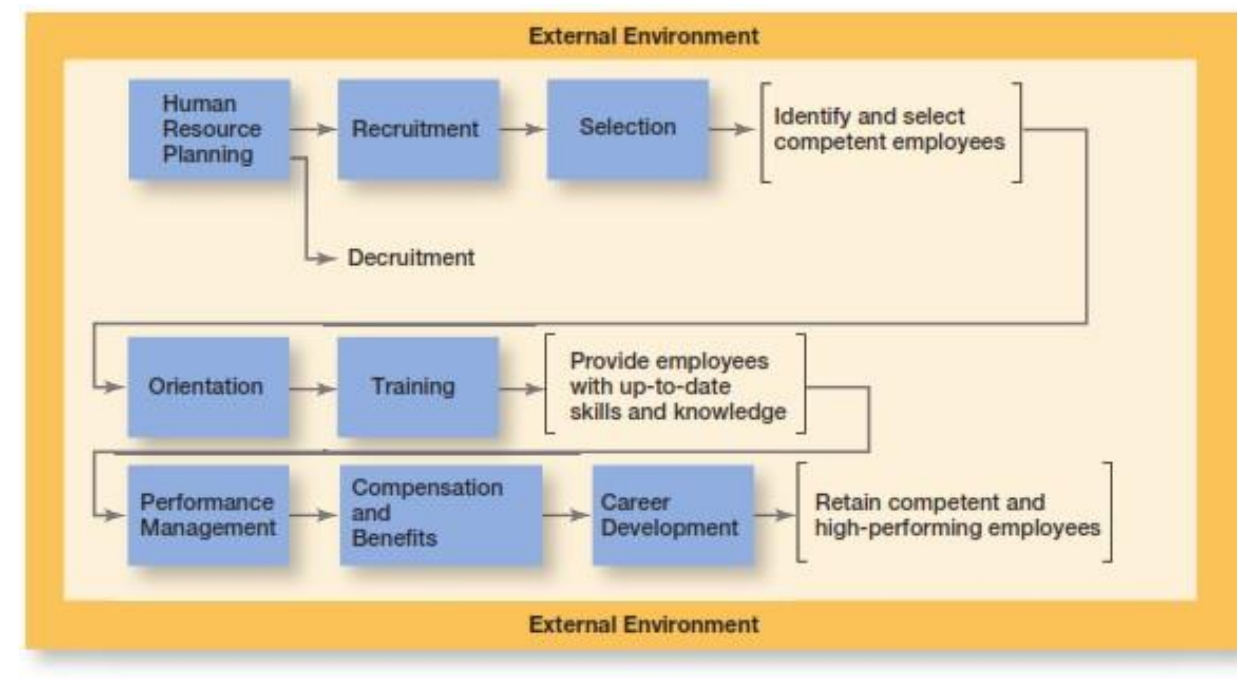

Source : Robbins \& Coulter (2016)

Figure 1. HRM Process

\section{Competency Characteristics}

Competence describes the ability of a person at work to carry out duties and responsibilities effectively so as to achieve professional quality standards. Spencer and Spencer (1993) quoted by Wibowo stated that "competence is the basic foundation of people's characteristics and indicates how to behave or think, equate situations and support for a long period of time". There are five types of competency characteristics according to (Wibowo, 2007):

1) Motives are things that people consistently think or want that cause one's actions.

2) Traits are physical characteristics and consistent responses to situations or information.

3) Self-concept (self-concept) is the attitudes, values, or image of a person's self-image.

4) Knowledge (knowledge) is information that a person has in a certain specific field.

5) Skills are the ability of a person to do certain physical or mental tasks.

Based on the description above, competence contains the inherent personality abilities of a person which can be applied to tasks at work. Competencies possessed by employees must be able to support the implementation of strategies in achieving organizational goals. So that competence has an effect on employee performance because the higher the competence of the employee, the demand for the role in his job will also increase.

\section{Employee Compensation and Performance}

In an organization, a motivated and performing workforce is needed high in order to meet the needs of the organization. One way to increase employee performance motivation is to get compensation. Compensation is all income in the form of money, direct or indirect goods received by employees in return for services provided to the company (Hasibuan, 2000).

\section{Compensation Indicator}

According to Simamora (2004), indicators for measuring employee compensation are: 
1) Wages and salaries

Wages are the basis of remuneration for production and maintenance workers. The difference between wages and salaries is that wages are generally in the form of hourly rates while wages apply weekly, monthly or annual rates.

2) Incentives

Incentives are additional compensation beyond the amount of salary or wages provided by the company.

3) Allowances

Allowances are health and life insurance, pension plans, and other benefits related to employment relationships.

4) Facilities

Facilities generally relate to something that employees can enjoy.

\section{Compensation Objectives}

The objectives of compensation include cooperation, job satisfaction, effective procurement, motivation, employee stability, discipline and influence from labor unions and the government. Hasibuan (2012: 121) suggests compensation objectives, namely:

1) Cooperation ties

In conducting a cooperation agreement, employees must do their job well, while the leadership is also required to pay compensation in accordance with the previously agreed agreement.

2) Job satisfaction

When getting compensation, employees can meet their needs so that they will get job satisfaction from their position.

3) Effective procurement

Procurement of qualified employees will be easier when the company provides compensation to employees who are large enough.

4) Motivation

Managers will find it easier to motivate employees when they are given compensation.

5) Employee stability

Providing compensation based on the principle of fairness, the stability of employees is more guaranteed because turnover is relatively small.

6) Discipline

The provision of large enough compensation will make employees to be disciplined and be better and comply with applicable regulations.

7) Trade union influence

Giving good compensation will reduce the influence of the union and employees will focus on their work.

8) Government influence

If compensation is provided in accordance with the applicable labor law, government intervention can be avoided.

\section{Type of Compensation}

The compensation provided by the company to employees has several types. According to Sofyandi (2008) compensation is generally divided into two types, namely:

1. Direct Compensation 
Direct compensation is compensation given to an employee in return for the work he does for the company. Examples are salaries, incentives, bonuses and job allowances.

2. Indirect Compensation

Indirect compensation is the provision of compensation to employees as a company effort to improve employee welfare. Examples are the allowances, facilities and services provided by the company.

One way to increase employee motivation and performance is through compensation for employees. Then the greater the compensation the company provides to its employees, the more employee performance will be in achieving organizational goals.

\section{Leadership and Employee Performance}

Leadership is the ability to influence a group to achieve goals (Robbins \& Coulter, 2018). Leadership is a series of structuring activities in the form of the ability to influence the behavior of others in certain situations so that they are willing to work together to achieve predetermined goals (Sutarto, 1998).

Leadership is the ability to influence other people, namely the group in order to direct their behavior and ability to achieve organizational or group goals.

\section{Leadership Style}

Leadership style is a way for leaders to influence their subordinates. There are three kinds of leadership styles, namely autocratic, democratic or participatory, and laiszes-faire. Autocratic leadership faces more problems giving orders to subordinates, whereas democratic leadership tends to follow the opinion of leaders and employees. In laiszes-faire leadership the leader will provide leadership if asked.

According to Feriyanto and Triana (2015: 94) the leadership style possessed by a leader can be explained through three theoretical lines, namely:

1) Genetic theory (heredity)

This theory states that "leaders are born not made". Adherents of this theory argue that a leader will become a leader because he has been born with leadership talents.

2) Social theory

The essence of social theory is "leaders are made or educated rather than natural". Adherents of this theory argue that anyone can become a leader if equipped with knowledge.

3) Ecological theory

The essence of this theory is that a person will only succeed in being a good leader if he has leadership talents.

The leader will have a strong character and identity. These characters are used as special characteristics that distinguish a person from others. Employee performance cannot be separated from the leadership style possessed by the leader. Leaders who carry out their duties properly will become role models and role models for their members. And with the existence of a good relationship between the leader and its members will improve performance in achieving organizational goals. Therefore, leadership attitude has an effect on employee performance.

The development of an increasingly modern era from any point of view, especially in the field of technology, has made many jobs in companies replaced by modern technology. 
However, besides all that, the role of employees cannot be replaced because it is a basic need that will continue to exist in organizations and companies. From the analysis we have done, it can be concluded that there are factors that greatly affect employee performance, especially three points, namely the competency factor, compensation factor, and leadership style. Competence contains the inherent personality abilities of a person which can be applied to tasks at work. Competencies possessed by employees must be able to support the implementation of strategies in achieving organizational goals. So that competence has an effect on employee performance because the higher the competence of the employee, the more demands on the role in his job will increase.

One way to increase employee motivation and performance is through compensation for employees. Then the greater the compensation the company provides to its employees, the more employee performance will be in achieving organizational goals. In addition, the leader will also have a strong character and identity. These characters are used as special characteristics that distinguish a person from others. Employee performance cannot be separated from the leadership style possessed by the leader. Leaders who carry out their duties properly will become role models and role models for their members. And with the existence of a good relationship between the leader and its members will improve performance in achieving organizational goals. Therefore, leadership attitudes affect employee performance. So it can be concluded that these three factors are very influential on employee performance. $* * * *$ (taken from the conclusion)

\section{Conceptual Framework}

Based on a theoretical study and the relationship between variables, the model or Conceptual Framework of this article in order to construct a hypothesis is as follows:

1) The Effect of Competence on Employee Performance based on research results: (Ansori \& Ali, 2017), and (Ridwan et al., 2020).

2) The Effect of Compensation on Employee Performance based on research results: (Riyanto, Pratomo, et al., 2017), (Purba et al., 2017), and (Paul \& Resources, 2000)

3) The influence of leadership on employee performance based on research results: (Limakrisna et al., 2016), (Bastari et al., 2020), (Anwar et al., 2020), (Ali, Mukhtar, et al., 2016), (Djoko Setyo Widodo, P. Eddy Sanusi Silitonga, 2017), (Chauhan et al., 2019), and (Elmi et al., 2016).

From theoretical studies and previous research and based on research objectives, the framework of this article for further research is as follows. 


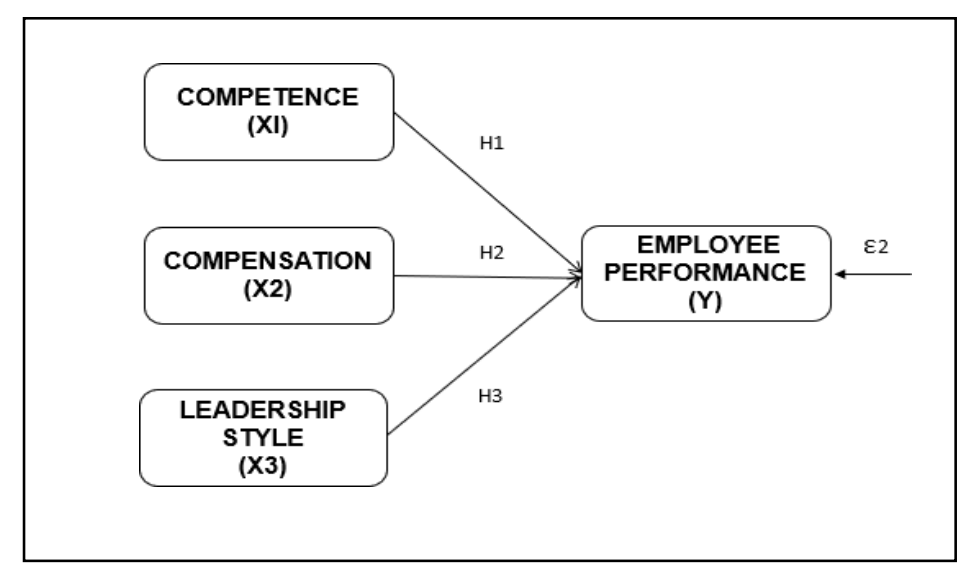

Figure 2. Conceptual Framework

\section{Discussion}

This article analyzes and discusses the variables of Human Resource Management (HRM), namely: Employee Performance, Competence, Compensation and Leadership Style.

\section{1) Competence has a relationship and affects employee performance}

Competence affects employee performance, this statement is based on articles from relevant and reviewed research, including: (Ansori \& Ali, 2017), (Ridwan et al., 2020).

This explains if a company or organization can assign employees according to their competencies, both technical and non-technical competencies. Then this will also be followed by an increase in employee performance in the form of technical skills, conceptual abilities, responsibilities, initiatives; and interpersonal relationship skills.

2) Compensation has a relationship and affects employee performance

Compensation affects employee performance, this statement is based on articles from relevant and reviewed research, including: (Riyanto, Pratomo, et al., 2017), (Purba et al., 2017), (Paul \& Resources, 2000) ).

This article explains that if the compensation provided by a company or organization can be given well, either in the form of financial compensation or non-financial compensation. Then this will also be followed by an increase in employee performance in the form of technical skills, conceptual abilities, responsibilities, initiatives; and interpersonal relationship skills.

3) Leadership Style has a relationship and affects employee performance

Leadership affects employee performance, this statement is based on articles from relevant and reviewed research, including: (Limakrisna et al., 2016), (Bastari et al., 2020), (Anwar et al., 2020), (Ali, Mukhtar, et al., 2016), (Djoko Setyo Widodo, P. Eddy Sanusi Silitonga, 2017), (Chauhan et al., 2019), (Elmi et al., 2016).

This article indicates that if a leader in a company or organization has intelligence, respect for his subordinates, is able to motivate, and is able to have good cooperation with his subordinates, this will also be followed by an increase in employee performance, both in the form of technical abilities and abilities. conceptual, responsibility, initiative; and interpersonal relationship skills. 


\section{CONCLUSIONS AND RECOMMENDATIONS}

\section{Conclusions}

Based on the formulation of the article, the results and discussion that are reviewed and discussed in this article, it can be concluded that to build a hypothesis for further research is:

1) Competence Influences Employee Performance

2) Compensation Affects Employee Performance

3) Leadership Style Influences Employee Performance

\section{Recommendations}

In relation to the results of the analysis above, it is hoped that all companies and organizations can maximize employee performance by increasing various supporting factors that affect employee performance. In addition, it is also hoped that the company will continue to improve the quality and quantity given in relation to the company's output in order to advance the company's development. This paper can also be developed again with more detailed methods both qualitative and quantitative in nature.

\section{BIBLIOGRAPHY}

Agussalim, M., Ayu Rezkiana Putri, M., \& Ali, H. (2016). Analysis work discipline and work spirit toward performance of employees (case study tax office Pratama two Padang). International Journal of Economic Research.

Agussalim, M., Kristin, M., \& Ali, H. (2016). Role of revolving loan program community national urban self (PNPM MP) against poverty prevention in Padang. International Journal of Applied Business and Economic Research.

Ali, H., Limakrisna, N., \& Jamaluddin, S. (2016). Model of customer satisfaction: The empirical study at Bri in Jambi. International Journal of Applied Business and Economic Research.

Ali, H., Mukhtar, \& Sofwan. (2016). Work ethos and effectiveness of management transformative leadership boarding school in the Jambi Province. International Journal of Applied Business and Economic Research.

Ali, H., \& Limakrisna, N. (2013). Metodologi Penelitian (Petunjuk Praktis untuk Pemecahan Masalah Bisnis, Penyusunan Skripsi, Tesis, dan Disertasi). Deeppublish: Yogyakarta.

Ansori, A., \& Ali, H. (2017). Analisis Pengaruh Kompetensi Dan Promosi Terhadap Kinerja Pegawai Negeri Sipil Pada Sekretariat Daerah Kabupaten Bungo. Jurnal Ilmiah Universitas Batanghari Jambi. https://doi.org/10.33087/jiubj.v15i1.198

Anwar, K., Muspawi, M., Sakdiyah, S. I., \& Ali, H. (2020). The effect of principal's leadership style on teachers' discipline. Talent Development and Excellence.

Author. Pengertian Kompetensi : Definisi, Jenis-jenis, dan Manfaat Kompetensi. [Online]

Tersedia : https://www.maxmanroe.com/vid/manajemen/pengertian-kompetensi.html. [7 Agustus 2020]

Bastari, A., -, H., \& Ali, H. (2020). DETERMINANT SERVICE PERFORMANCE THROUGH MOTIVATION ANALYSIS AND TRANSFORMATIONAL

LEADERSHIP. International Journal of Psychosocial Rehabilitation. https://doi.org/10.37200/ijpr/v24i4/pr201108 
Bayu, C. 2014. Sumberdaya Manusia (Human Resource Management). [Online] Tersedia : http://chandrabayuu.blogspot.com/2014/03/kompensasi.html. [7 Agustus 2020]

Brata, Husani, Hapzi, B. H. S. A. (2017). Saudi Journal of Business and Management Studies Competitive Intelligence and Knowledge Management: An Analysis of the Literature. Saudi Journal of Business and Management Studies. https://doi.org/10.21276/sjbms

Chauhan, R., Ali, H., \& Munawar, N. A. (2019). BUILDING PERFORMANCE SERVICE THROUGH TRANSFORMATIONAL LEADERSHIP ANALYSIS, WORK STRESS AND WORK MOTIVATION (EMPIRICAL CASE STUDY IN STATIONERY DISTRIBUTOR COMPANIES). Dinasti International Journal of Education Management And Social Science. https://doi.org/10.31933/dijemss.v1i1.42

Desfiandi, A., Desfiandi, A., \& Ali, H. (2017). Composite Stock Price Index (IHSG) Macro Factor in Investment in Stock (Equity Funds). International Journal of Economics and Financial Issues.

Djojo, A., \& Ali, H. (2012). Information technology service performance and client's relationship to increase banking image and its influence on deposits customer banks loyalty (A survey of Banking in Jambi). In Archives Des Sciences.

Djoko Setyo Widodo, P. Eddy Sanusi Silitonga, \& H. A. (2017). Organizational Performance: Analysis of Transformational Leadership Style and Organizational Learning. Saudi Journal of Humanities and Social Sciences. https://doi.org/10.21276/sjhss.2017.2.3.9

Dtf, Ainun. 2020. Pengertian Kepemimpinan : Tujuan, Teori, Fungsi, dan Contoh

Leadership. [Online] Tersedia : https://salamadian.com/pengertian-kepemimpinan/.

[10 Agustus 2020]

Elmi, F., Setyadi, A., Regiana, L., \& Ali, H. (2016). Effect of leadership style, organizational culture and emotional intelligence to learning organization: On the Human Resources Development Agency of Law and Human Rights, Ministry of Law and Human Rights. International Journal of Economic Research.

Harini, S., Hamidah, Luddin, M. R., \& Ali, H. (2020). Analysis supply chain management factors of lecturer's turnover phenomenon. International Journal of Supply Chain Management.

Limakrisna, N., Noor, Z. Z., \& Ali, H. (2016). Model of employee performance: The empirical study at civil servants in government of west java province. International Journal of Economic Research.

Ma'ruf. Pengertian Kompensasi, Indikator, Tujuan dan Jenisnya Menurut Para Ahli.

[Online] Tersedia : https://www.akuntansilengkap.com/manajemen/pengertian-

kompensasi-indikator-tujuan-jenis/. [5 Agustus 2020]

Paul, R., \& Resources, C. (2000). 0 r g a n. 73-77.

Prayetno, S., \& Ali, H. (2017). Analysis of advocates organizational commitment and advocates work motivation to advocates performance and its impact on performance advocates office. International Journal of Economic Research.

Prihartono, \& Ali, H. (2020). The promises ethics and marketing concept strategy as a 
competitive advantage on private higher education (A survey on perception of product attributes and promotion mix in Indonesia). Talent Development and Excellence.

Purba, C. B., Arzio, \& Ali, H. (2017). The influence of compensation, working environment and organization culture on working productivity of BPJS (workers social security agency) employment staff in Rawamangun Branch. Man in India.

Ridwan, M., Mulyani, S. R., \& Ali, H. (2020). Building behavior and performance citizenship: Perceived organizational support and competence (case study at SPMI private university in west Sumatra). International Journal of Psychosocial Rehabilitation. https://doi.org/10.37200/IJPR/V24I6/PR260195

Riyanto, S., Pratomo, A., \& Ali, H. (2017). EFFECT OF COMPENSATION AND JOB INSECURITY ON EMPLOYEE ENGAGEMENT (STUDY ON EMPLOYEE OF BUSINESS COMPETITION SUPERVISORY COMMISSION SECRETARIAT). International Journal of Advanced Research. https://doi.org/10.21474/ijar01/4139

Riyanto, S., Sutrisno, A., \& Ali, H. (2017). International Review of Management and Marketing The Impact of Working Motivation and Working Environment on Employees Performance in Indonesia Stock Exchange. International Review of Management and Marketing.

Robbins, S. P., \& Coulter, M. (2016). Management Thirtheenth Edition. Dalam Management Thirteenth Edition (hal. 355). Pearson.

Sulaeman, A. S., Waluyo, B., \& Ali, H. (2019). Making dual procurement and supply chain operations: Cases in the indonesian higher education. International Journal of Supply Chain Management. 